(c) American Dairy Science Association, 2007.

\title{
Effect of Monopropylene Glycol on Luteinizing Hormone, Metabolites, and Postpartum Anovulatory Intervals in Primiparous Dairy Cows
}

\author{
L. M. Chagas, ${ }^{1}$ P. J. S. Gore, S. Meier, K. A. Macdonald, and G. A. Verkerk \\ Dexcel, Private Bag 3221, Hamilton, New Zealand
}

\begin{abstract}
This study examined the effect of monopropylene glycol (MPG) supplementation on LH secretion, postpartum interval to first ovulation, and milk production in heifers calving with poor body condition score (BCS). Forty-seven heifers were allocated to 3 treatments: 1$)$ heifers with high $\mathrm{BCS}(\mathrm{BCH} ; \mathrm{n}=13)$ that calved at a BCS of 3.4 (BCS scale of 1 to 5); 2) heifers with low BCS (BCL; $\mathrm{n}=17$ ) that calved at a BCS of 2.8; and 3) heifers with low BCS that calved at a BCS of 2.8 and were assigned to receive MPG supplementation (BCL + MPG; $\mathrm{n}=17$ ) and grazed pasture ad libitum. Monopropylene glycol was drenched $(250 \mathrm{~mL})$ twice daily for 16 wk after calving. Patterns of change in plasma LH were measured at 2 and $5 \mathrm{wk}$ after calving. Pulsatile release of LH at 2 and 5 wk was greater in BCL + MPG and $\mathrm{BCH}$ cows compared with the BCL control cows. The $\mathrm{BCL}+\mathrm{MPG}$ cows had lower NEFA concentrations than did the BCL cows during wk 1 to 6 after calving. At 12 wk postpartum, the proportion of cows cycling was 77 , 82 , and $28 \%$ for the BCH, BCL + MPG, and BCL treatments, respectively. Mean milk fat yield was greater for the $\mathrm{BCH}$ treatment during the first 12 wk postpartum compared with the BCL + MPG or BCL treatments, which did not differ from each other. Results of this study indicate that MPG supplementation reduced the interval from calving to first ovulation in heifers having poor body condition at calving.
\end{abstract}

Key words: dairy cow, pasture system, monopropylene glycol, postpartum anestrus

\section{INTRODUCTION}

A prolonged postpartum anovulatory period in dairy cows is of major economic importance in terms of cow productivity. In a pasture-based system, numerous studies link reproductive performance to body condition and nutritional status, with cows well conditioned at calving resuming estrual activity earlier than cows of

Received April 12, 2006.

Accepted October 30, 2006.

${ }^{1}$ Corresponding author: lucia.chagas@dexcel.co.nz poorer body condition (Grainger et al., 1982; Burke et al., 1995). Postpartum BCS has been related to energy balance, which is influenced by both pre- and postcalving nutrition and milk production (Roche et al., 2000).

Lack of ovulation and reduced postpartum ovarian activity could be the result of an inhibition of the hypothalamo-pituitary-ovarian axis. Reduced LH pulse frequency has been suggested as a major factor limiting the resumption of postpartum ovulatory activity (Nett, 1987). Cows with low LH pulse frequency have an extended postpartum period of anovulation compared with cows with greater LH pulse frequency (Butler et al., 1981).

Postpartum negative energy balance in cows occurs as energy requirements for production and maintenance exceed energy intakes, resulting in mobilization of body tissues (Butler et al., 1981). Negative energy balance during the first $3 \mathrm{wk}$ postpartum is positively correlated with days to first ovulation (Butler et al., 1981). Negative energy balance is associated with reduced postpartum concentrations of LH that may adversely influence follicular development (Butler and Smith, 1989). Negative energy balance has also been associated with reduced blood glucose, insulin, and IGF-I as well as increased NEFA and ketone bodies, all of which are indicative of reduced gluconeogenesis and enhanced fat mobilization and ketogenesis.

When administered orally, monopropylene glycol (MPG) is a glucogenic precursor that bypasses the rumen and is absorbed in the duodenum and metabolized to propionate in the liver (Emery et al., 1964). Administration of MPG has been shown to be effective at reducing plasma NEFA and increasing glucose and insulin (Studer et al., 1993; Formigoni et al., 1996, Miyoshi et al., 2001).

Monopropylene glycol supplementation during negative energy balance has altered luteal function during the first estrous cycle after calving and reduced the postpartum period of anovulation (Formigoni et al., 1996). A daily oral administration of $500 \mathrm{~g}$ of $\mathrm{MPG}$ should provide 7.5 MJ of ME/d. Miyoshi et al. (2001) calculated energy balance using energy intake (feed) and energy output (milk and maintenance) and found no difference in energy balance between cows receiving 
MPG supplementation and control cows. Miyoshi et al. (2001) postulated that the effects of MPG were mediated primarily by inducing a spike in plasma insulin concentration; however, the mechanism whereby the MPG drench influences plasma insulin has not been established. A certain amount of MPG may be metabolized to propionate, which can stimulate pancreatic insulin secretion (Grummer et al., 1994), or MPG may stimulate insulin secretion directly (Studer et al., 1993). Previous studies indicate that supplementation with MPG may improve reproductive performance (Formigoni et al., 1996), preventing elevated concentrations of NEFA and concomitantly increasing plasma insulin and glucose during the postpartum period (Miyoshi et al., 2001).

This study was designed to determine the effect of MPG supplementation on the initiation of ovarian activity after calving in dairy heifers calving with poor BCS. We hypothesized that postpartum supplementation with MPG would stimulate LH pulse frequency and ovulation in heifers having poor BCS; increase their basal plasma concentrations of insulin, IGF-I, and leptin; and reduce their growth hormone $(\mathbf{G H})$ and NEFA levels.

\section{MATERIALS AND METHODS}

This experiment was conducted at Dexcel Dairy No. 5, Hamilton, New Zealand $\left(37^{\circ} 46^{\prime} \mathrm{S}, 175^{\circ} 18^{\prime} \mathrm{E}\right)$, and all procedures were approved by the Ruakura Animal Ethics Committee, Hamilton, New Zealand.

\section{Experimental Design and Treatments}

Forty-seven Holstein-Friesian heifers (2 yr old) were used that had conceived on a common date following $\mathrm{AI}$ at a synchronized estrus. During the last 5 mo of gestation, pasture allowances were managed to have 13 heifers calve at a BCS of $3.4(\mathbf{B C H}$, i.e., high BCS) and 34 heifers at a BCS of 2.78 (BCL, i.e., low BCS), on a 1 to 5 scale $(1=$ emaciated, $5=$ obese $)$. After calving, 34 BCL heifers were allocated randomly to one of 2 groups, a control group (BCL; $\mathrm{n}=17$ ) and a group receiving MPG treatment (BCL + MPG; $\mathrm{n}=17)$. Monopropylene glycol (Agri-feeds Ltd., Mount Maunganui, New Zealand) was administered as an oral drench $(250 \mathrm{~mL})$ twice daily before each milking, beginning at calving until the end of the AI period (approximately 150 DIM). Allocation to the treatment was balanced for BW and genetic merit for milk production. Females were weighed and BCS was assessed weekly from $19 \mathrm{wk}$ before until and $10 \mathrm{wk}$ after calving, and then every 2 wk until the end of lactation.

\section{Grazing Management}

The pasture offered was predominantly perennial ryegrass (Lolium perenne L.) and white clover (Trifolium repens), with $<20 \%$ weeds and other grasses (Dactylis glomerata; Poa species). Before calving, all heifers grazed separately in 0.25 -ha paddocks treatments, receiving either $36 \mathrm{~m}^{2} /$ heifer per day $(\mathrm{BCH})$ or $21 \mathrm{~m}^{2} /$ heifer per day (BCL) and achieving a DMI of either 10.6 or $4.9 \mathrm{~kg}$ of $\mathrm{DM} /$ heifer per day, respectively.

Heifers were allocated to fresh pasture each morning. Pasture allocations were visually assessed, and assessors were calibrated weekly by cutting a range of pasture yields, representative of pre- and postgrazing yields (Thom et al., 1986). The DMI of each treatment was calculated daily from pregrazing and postgrazing pasture mass (Roche et al., 1996). Pregrazing pasture masses were $3,566 \pm 489$ and $44,75 \pm 352 \mathrm{~kg}$ of DM/ha (mean $\pm \mathrm{SD}$ ) for all BCL heifers and the $\mathrm{BCH}$ treatment, respectively. Postgrazing residual pasture masses were $924 \pm 321$ and 1,500 $\pm 330 \mathrm{~kg}$ of DM/ha for BCL heifers and the $\mathrm{BCH}$ treatment, respectively.

After calving, all cows grazed together. Cows were allocated to fresh pasture following each milking. The pregrazing pasture mass was $3,819 \pm 583 \mathrm{~kg}$ of DM/ha and the postgrazing residual pasture mass was 2,086 $\pm 478 \mathrm{~kg}$ of $\mathrm{DM} / \mathrm{ha}$.

\section{Blood Sampling}

Blood samples were collected weekly, from 3 wk before until $10 \mathrm{wk}$ after calving. Blood samples were collected before new pasture was offered (approximately $0800 \mathrm{~h}$ ), and before milking and MPG drenching (postpartum).

Postpartum patterns of $\mathrm{LH}$ release were determined at 2 and $5 \mathrm{wk}$ in blood samples collected at 15-min intervals (commencing at $0600 \mathrm{~h}$ ) for $16 \mathrm{~h}$, including during milking. Jugular catheters were inserted under local anesthesia to facilitate frequent collection.

All blood samples were collected into $10-\mathrm{mL}$ Vacutainer tubes (Becton Dickinson, Franklin Lakes, NJ) containing sodium heparin and were immediately placed in iced water. Blood samples were centrifuged at $1,120 \times \mathrm{g}$ for $12 \mathrm{~min}$, within $1 \mathrm{~h}$ of collection. Aliquots of plasma were stored at $-20^{\circ} \mathrm{C}$ until assayed for $\mathrm{LH}$, insulin, IGF-I, GH, leptin, glucose, BHBA, and NEFA concentrations.

\section{Postpartum Anovulatory Intervals and Milk Production}

Progesterone concentrations were measured in fresh whole milk samples collected thrice weekly before the start of each milking. The postpartum anovulatory in- 
terval or postpartum interval to first ovulation was defined as the interval from calving to the first of 2 consecutive sampling days when progesterone concentrations in milk were $>1 \mathrm{ng} / \mathrm{mL}$.

Weekly milk yields were measured throughout lactation using inline milk meters (Tru-Test, Auckland, New Zealand) and subsamples were collected to measure protein, fat, and lactose concentrations (MilkoScan FT120; Foss, Hillerød, Denmark).

\section{Hormone and Metabolite Assays}

Plasma glucose, BHBA, and NEFA were measured by the hexakinase colorimetric method using a Hitachi 717 analyzer (Roche, Basel, Switzerland) at $30^{\circ} \mathrm{C}$ by Alpha Scientific Ltd. (Hamilton, New Zealand). The intra- and interassay coefficients of variation were 4 and $6 \%$, respectively.

Insulin was measured in duplicate using a doubleantibody RIA (Hales and Randle, 1963). Insulin antiserum (GP2, 21/7/80), donated by Dr. Peter Wynn (Commonwealth Scientific and Industrial Research Organisation, Division of Animal Production, Blacktown, New South Wales, Australia), was raised in guinea pigs against bovine insulin (BI 4499; Eli Lilly Pty. Ltd., West Ryde, New South Wales, Australia). Parallelism of the assay, more than $97 \%$, was calculated using serial dilutions of 3 samples of bovine plasma containing an elevated concentration of insulin. The intra- and interassay coefficients of variation were 2 and $4 \%$, respectively. The limit of detection of the assay was 0.89 $\mu \mathrm{U} / \mathrm{mL}$.

Plasma IGF-I was assayed in duplicate by doubleantibody RIA (Gluckman et al., 1983) with human recombinant IGF-I (ARM4050; Amersham-Pharmacia Biotech, Buckinghamshire, UK) and anti-human IGF-I antiserum (AFP4892898; National Hormone and Pituitary Program of the National Institute of Diabetes and Digestive and Kidney Diseases, National Institutes of Health, Bethesda, MD; final dilution; 1:360,000) following acid-ethanol extraction and cryoprecipitation (Breier and Gluckman, 1991). The percentage recovery of IGF-I was $92 \pm 5.5 \%$, calculated from 10 samples containing a known added amount of IGF-I and measured in triplicate. Parallelism of the assay, more than $97 \%$, was calculated using serial dilutions of 3 samples of bovine plasma containing an elevated concentration of IGF-I. The intra- and interassay coefficients of variation were 6 and 8\%, respectively. The limit of detection of the assay was $1 \mathrm{ng} / \mathrm{mL}$.

Leptin was measured in duplicate using a doubleantibody RIA (Blache et al., 2000). The limit of detection of the assay was $0.1 \mathrm{ng} / \mathrm{mL}$. The intra- and interassay coefficients of variation were 4 and $7 \%$, respectively.

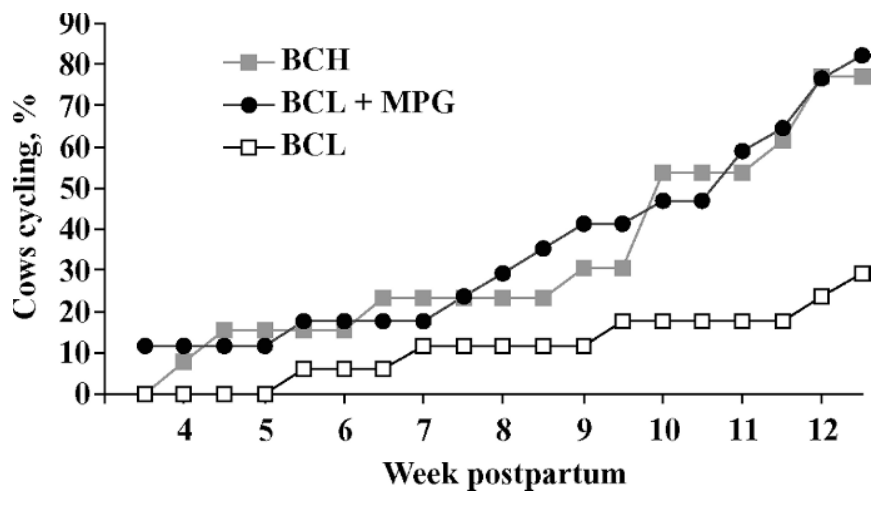

Figure 1. Percentage of cows cycling during the first 13 wk after calving. Heifers calved at BCS of $3.4(\mathrm{BCH} ; \mathrm{n}=13), 2.8(\mathrm{BCL} ; \mathrm{n}=$ 17), and 2.8 drenched with monopropylene glycol (BCL + MPG; $\mathrm{n}=$ 17) twice daily for $16 \mathrm{wk}$ after calving.

Plasma was assayed for GH in duplicate by doubleantibody RIA (Downing et al., 1995) with ovine GH (NIDDK-I-5; National Hormone and Pituitary Program of the National Institute of Diabetes and Digestive and Kidney Diseases) and anti-oGH antiserum (NIDDKanti-oGH-3; National Hormone and Pituitary Program of the National Institute of Diabetes and Digestive and Kidney Diseases; final dilution 1:300,000) following acid-ethanol extraction and cryoprecipitation (Breier and Gluckman, 1991). The parallelism of the assay, more than $98 \%$, was calculated using serial dilutions of 3 samples of bovine plasma containing an elevated concentration of GH. The intra- and interassay coefficients of variation were 5 and $9 \%$, respectively. The assay detection limit was $0.06 \mathrm{ng} / \mathrm{mL}$.

Plasma concentrations of LH were measured using a double-antibody RIA with rabbit antiserum against ovine LH (R\#2; AgResearch Invermay, Mosgiel, New Zealand), with standards and tracer prepared using ovine LH (NIDDK-oLH-I-2; McDougall, 1994). The intra- and interassay coefficients of variation were 6 and $10 \%$, respectively. The sensitivity of the assay was 0.2 $\mathrm{ng} / \mathrm{mL}$.

Concentrations of progesterone in milk were measured using a solid-phase ${ }^{125}$ I-labeled RIA kit (Coat-ACount; DPC, Los Angeles, CA; Dieleman and Bevers, 1987). The intraassay coefficient of variation was $6 \%$, whereas the interassay coefficients of variation were $4.1 \%$ for standard concentrations of $4.4,3.0$, and 0.4 $\mathrm{ng} / \mathrm{mL}$.

\section{Statistical Analysis}

Differences among treatments in BW, BCS, and hormone and metabolite concentrations were analyzed as a repeated-measures analysis using REML to fit a mixed 


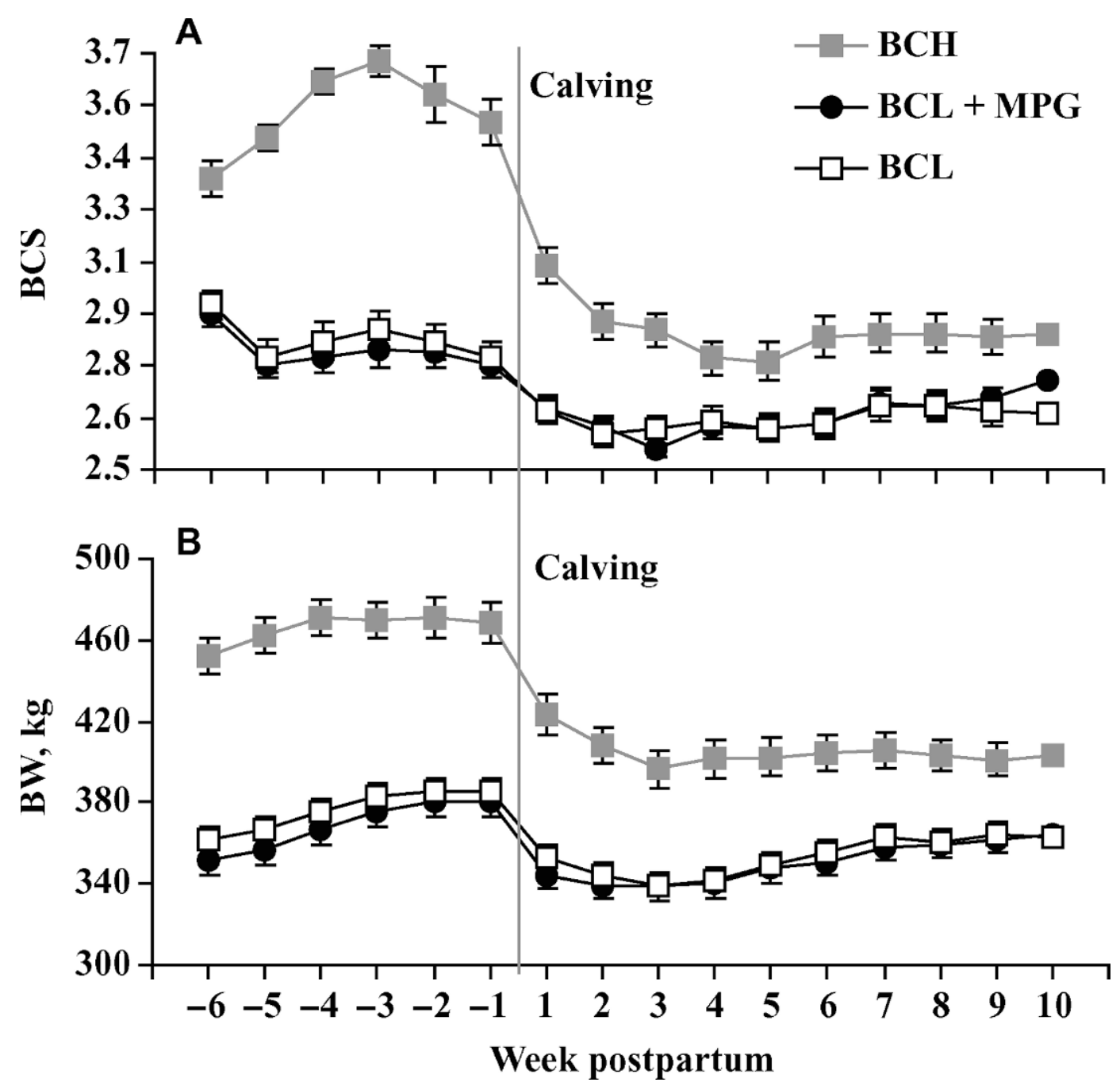

Figure 2. Mean BCS and BW from 5 wk before until 11 wk after calving. Heifers calved at BCS of $3.4(B C H ; n=13), 2.8(B C L ; n=17)$, and 2.8 drenched with monopropylene glycol $(\mathrm{BCL}+\mathrm{MPG} ; \mathrm{n}=17)$ twice daily for $16 \mathrm{wk}$ after calving. Error bars represents the SEM.

model that included cow and time within cow as random effects and treatment, time, and their interaction as fixed effects. A compound symmetry covariance structure was used to model collection times within cows, allowing for heterogeneity of the variances at each time point. This analysis was carried out separately on prepartum and postpartum measurements. Milk production for the first $10 \mathrm{wk}$ of lactation was analyzed using this same method. Data at each time point are presented because, in general, no significant time $\times$ treatment interactions were detected.

The effect of treatment on the proportion of cows that had ovulated by $84 \mathrm{~d}$ after the mean calving date was analyzed using generalized linear models with a binomial error distribution and logit link function. All statistical analyses used GenStat 8.1 (VSN International Ltd., Hemel Hempstead, UK).
The LH pulse frequency was established by visual appraisal of individual profiles; a peak was defined as any increase in LH concentration within two 15-min sampling intervals that was followed by a decline in concentration, with at least 3 sampling intervals (45 min) between the defined peak and succeeding baseline, occurring at a rate approximating the half-life of the LH (Zurek et al., 1995). Data for 2 BCL + MPG cows were removed from the $\mathrm{LH}$ analyses at $5 \mathrm{wk}$ postpartum because they had resumed estrous cycles.

\section{RESULTS}

Average postpartum anovulatory intervals (mean \pm $\mathrm{SE})$ were $62 \pm 4,60 \pm 3$, and $83 \pm 3 \mathrm{~d}$ for the $\mathrm{BCH}$, $\mathrm{BCL}+\mathrm{MPG}$, and BCL cows, respectively. This interval differed $(P<0.05)$ between the BCL cows compared 

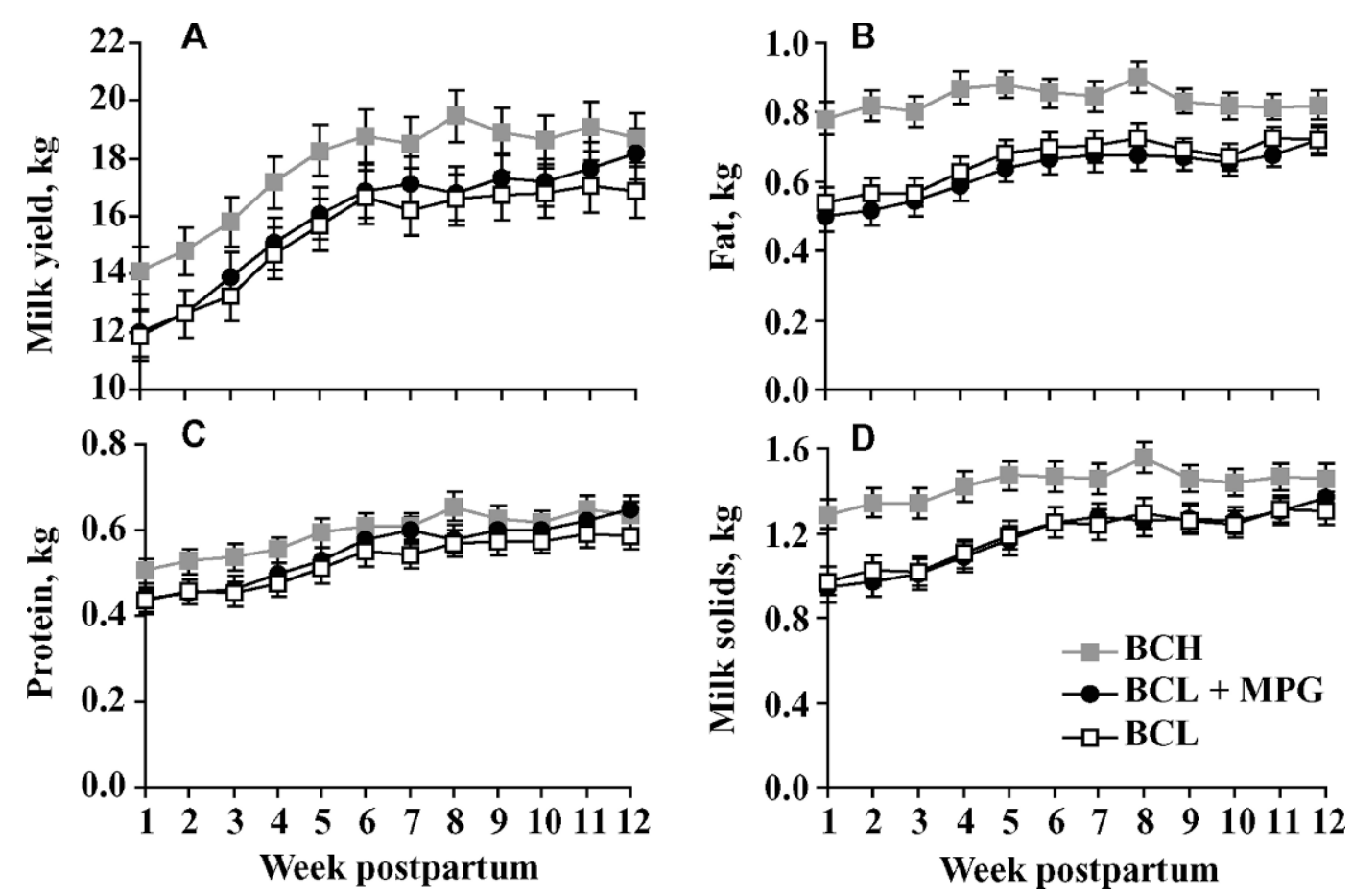

Figure 3. Mean milk yield, fat, protein, and milk solids $(\mathrm{kg})$ during the first 12 wk postpartum in heifers that calved at BCS of 3.4 (BCH; $\mathrm{n}=13), 2.8(\mathrm{BCL} ; \mathrm{n}=17)$, and 2.8 drenched with monopropylene glycol (BCL + MPG; $\mathrm{n}=17)$ twice daily for 16 wk after calving. Error bars represents the SEM.

with cows in the $\mathrm{BCH}$ and $\mathrm{BCL}+\mathrm{MPG}$ treatments (Figure 1). Because cows from the $\mathrm{BCH}$ and the $\mathrm{BCL}$ + MPG treatments ovulated earlier than the BCL cows, the percentages of cows cycling at the planned start of mating (12 wk) for each group (77, 82, and $28 \%$, respectively) also differed $(P<0.05)$ for cows in the $\mathrm{BCH}$ and $\mathrm{BCL}+\mathrm{MPG}$ treatments compared with those in the BCL treatment.

The number of cows pregnant to AI (first 6 wk of the mating period) did not differ among treatments and was $69 \%$ for $\mathrm{BCH}, 76 \%$ for BCL + MPG, and $46 \%$ for BCL. More $(P<0.05)$ cows were not pregnant after a 12 -wk mating period in the BCL treatment compared with the other 2 treatments. The final nonpregnant rates were $8 \%$ for $\mathrm{BCH}, 0 \%$ for $\mathrm{BCL}+\mathrm{MPG}$, and $35 \%$ for BCL.

Body condition and BW were greater $(P<0.05)$ for the $\mathrm{BCH}$ treatment compared with the BCL treatment from $5 \mathrm{wk}$ before to $12 \mathrm{wk}$ after calving (Figure 2). Body condition and BW did not differ between the BCL and $\mathrm{BCL}+\mathrm{MPG}$ treatments. At calving, heifers in the BCH treatment were heavier $(P<0.001)$ than those in the BCL treatment $(470 \pm 11$ and $384 \pm 11 \mathrm{~kg}$, respectively; Figure 2).

The mean milk yield was greater $(P<0.05)$ for the $\mathrm{BCH}$ treatment during the first $5 \mathrm{wk}$ and at $7 \mathrm{wk}$ after calving when compared with the BCL + MPG or BCL treatments. No difference was detected in the mean milk yield between the 2 BCL treatments (Figure 3 ). Mean milk solids and milk fat yield were greater $(P<$ 0.05 ) for the $\mathrm{BCH}$ treatment during the first $12 \mathrm{wk}$ after calving when compared with the BCL + MPG or BCL treatments. Mean milk protein yield was greater $(P<$ 0.05 ) for the $\mathrm{BCH}$ treatment at 3,4 , and 7 wk after calving, compared with the BCL treatment. No difference in mean milk protein yield was detected between the 2 BCL treatments (Figure 3).

Concentrations of IGF-I and glucose did not differ among treatments at any time. Further, no consistent differences were detected among treatments for basal plasma insulin concentrations (Figure 4).

Concentrations of BHBA and NEFA were greater $(P$ $<0.05$ ) pre- and postcalving in the $\mathrm{BCH}$ treatment compared with the BCL treatment. Cows in the BCL + MPG treatment had a reduced $(P<0.05)$ NEFA concentration compared with those in the BCL treatment during wk 1 to 6 after calving (Figure 4). The leptin concentration was greater $(P<0.05)$ for cows in the $\mathrm{BCH}$ treatment than those in the BCL treatment at 1 and 2 wk before calving and at 2 and $3 \mathrm{wk}$ after calving (Figure 4$)$. The pulsatile release of $\mathrm{LH}$ was greater $(P<0.05)$ in cows in the BCL + MPG and BCH treatments when compared with those in the BCL treatment at 2 and $5 \mathrm{wk}$ postpartum (Figure 5). 

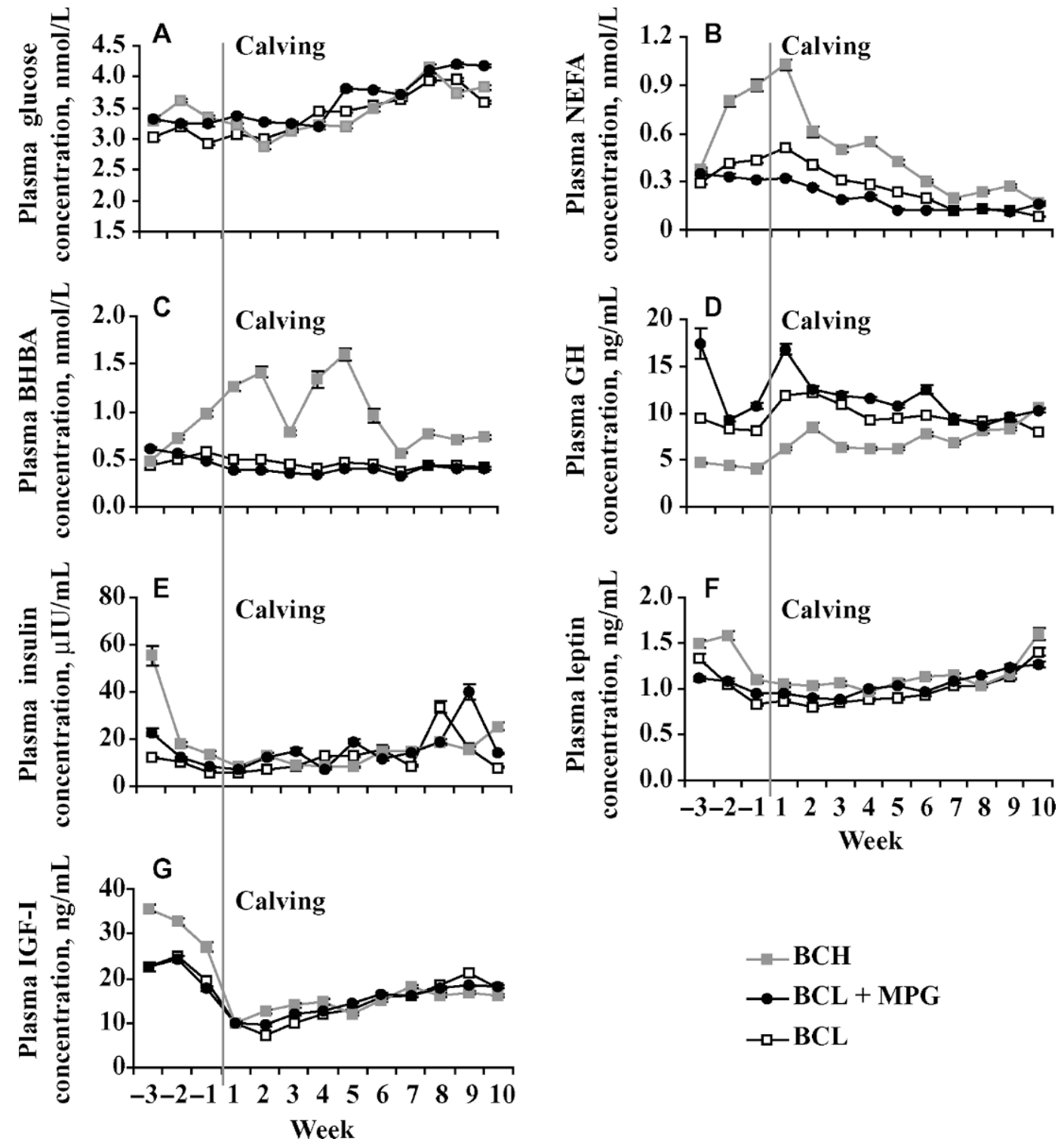

Figure 4. Mean values for plasma glucose, insulin, growth hormone (GH), IGF-I, leptin, BHBA, and NEFA concentration from 3 wk glycol (BCL + MPG; $n=17)$. Error bars represents the SEM.

\section{DISCUSSION}

Supplementation with MPG reduced the interval from calving to first ovulation in heifers that calved having a poor body condition. The effect of MPG on the duration of the postpartum anovulatory period was probably elicited through an increase in LH pulsatility. Reestablishment of pulsatile LH secretion is recognized as a key event in the return to ovarian cyclicity by the postpartum dairy cow (Canfield and Butler, 1990). The exact mechanism whereby MPG stimulates LH secretion has not been established. However, administration of MPG has been shown to induce a spike in the plasma insulin concentration (Miyoshi et al., 2001), and this increase in insulin might have stimulated the increase in LH pulse frequency observed in the present study. Alternatively, an increase in insulin concentration could promote the differentiation and maturation of dominant follicles during early lactation, thereby increasing the chance of a dominant follicle ovulating in response to a LH surge (Beam and Butler, 1999).

Negative energy balance impairs reproductive activity by suppressing the release of $\mathrm{GnRH}$ and reducing the LH pulse frequency (Schillo, 1992). Plasma NEFA and energy balance are correlated in some studies, with 


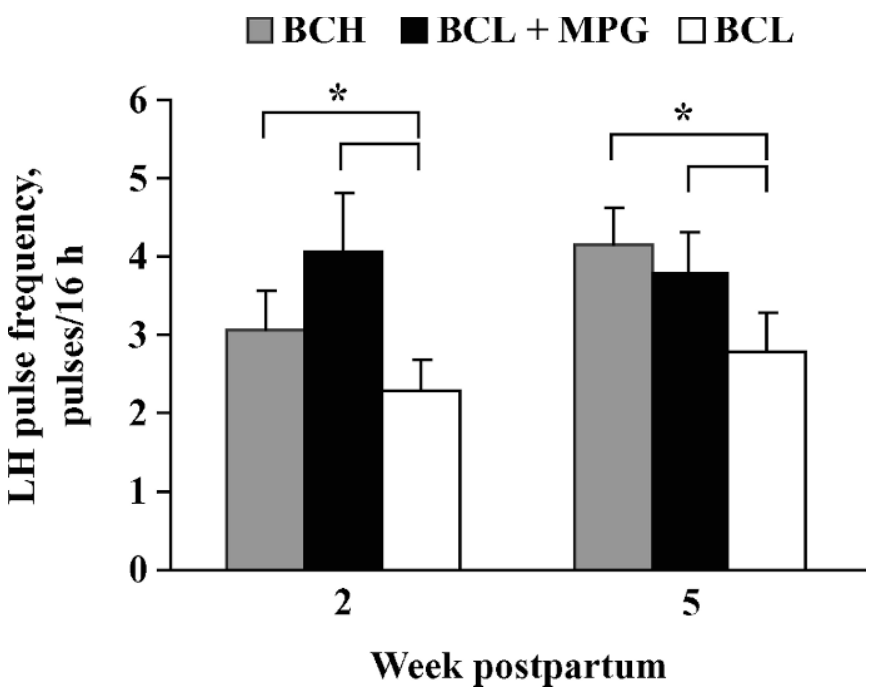

Figure 5. Mean LH pulse frequency at 2 and 5 wk after calving in heifers calving at BCS of $3.4(\mathrm{BCH} ; \mathrm{n}=13), 2.8(\mathrm{BCL} ; \mathrm{n}=17)$, and 2.8 drenched with monopropylene glycol (BCL + MPG; $\mathrm{n}=17$ ) twice daily for 16 wk after calving. Error bars represents the SEM.

high NEFA concentrations being indicative of negative energy balance. Therefore, plasma concentrations of NEFA have been proposed as a signal of energy status (Canfield and Butler, 1990). In our study, this was not observed, because cows in the BCL treatments with or without MPG supplementation had lower mean plasma NEFA concentrations compared with those in the $\mathrm{BCH}$ treatment. This possibly could be explained by the availability of fat reserves for mobilization that were reduced in both BCL treatments. It is interesting to note that the BCL + MPG treatment also had a lower mean plasma NEFA concentration compared with the BCL group during wk 1, 3, and 5, despite cows in these 2 treatments having similar BW and BCS during the experiment. This is possibly in line with a hypothesis (Canfield and Butler, 1990) that NEFA concentrations reflect energy balance. In the present study, it was not possible to determine whether the ability of MPG to minimize increases in NEFA concentrations after calving was beneficial by improving the metabolic status. Energy balance was not determined in the present study because it was not possible to determine accurate individual feed intakes. Similar changes in NEFA concentration after administration of MPG have been observed in several studies (Studer et al., 1993; Formigoni et al., 1996; Miyoshi et al., 2001). However, Miyoshi et al. (2001) found no difference in energy balance in heifers or multiparous cows drenched with $500 \mathrm{~mL}$ of MPG from $\mathrm{d} 7$ to 42 after calving and control cows. The energy balance used by Miyoshi et al. (2001) was calculated on the basis of energy intake (feed) and energy output (milk and maintenance). In their case, it was not possible to determine whether the effects of MPG were manifested through improved energy balance.

Prolonged postpartum anovulatory intervals negatively influence first-service conception rates and overall reproductive performance. Our experiment was designed to demonstrate whether MPG supplementation decreased the interval to first postpartum ovulation in lactating primiparous cows calving with a poor body condition. Our study demonstrated that heifers calving with a poor BCS were more likely to have a longer postpartum anovulatory interval than those calving at an optimal BCS or those having a poor BCS of 2.8 and drenched with MPG. This result clearly demonstrates that MPG may be useful to treat "at risk" cows (e.g., young cows that calve with a poor body condition) to improve their reproductive performance. A seasonal dairy system requires that cows resume cyclicity, display estrus, be mated, and conceive within $83 \mathrm{~d}$ postpartum. An early return to estrus is therefore important to maintain the necessary concentrated calving pattern.

Body condition and BW at calving are known to influence the duration of the postpartum anovulatory period (Grainger et al., 1982; Burke et al., 1995). The relationship between body condition at calving and postpartum anovulation is nonlinear. Dietary restriction during late gestation in beef females results in weight loss and decreased body fat at calving, which reduces the number of cows and heifers that return to estrus early in a defined breeding season (Wettemann, 1994). Although all treatments received a generous and similar pasture allowance after calving, the cows in the BCL treatment needed $21 \mathrm{~d}$ more to ovulate when compared with better-conditioned primiparous cows. The fact that the BCL cows drenched with MPG after calving ovulated earlier than those in the BCL treatment without MPG demonstrates that it is possible to override the effects of poor BCS at calving without having to increase energy availability.

In agreement with previous studies (Flux, 1950; Grainger et al., 1982), our results showed a positive effect of BCS at calving on subsequent milk yield. In our study, heifers calving at a greater BCS produced more milk than those having a poor BCS, despite all heifers receiving a generous pasture allowance after calving.

Postpartum anestrus is a complex phenomenon controlled by many factors that act either individually or in concert to decrease the production potential of dairy cows. It is important to consider the benefits and costs of different management protocols applied to decrease postpartum anestrus (changing the duration of the breeding season, using strategic supplementation to alter energy levels and body condition at calving). Drench- 
ing with $250 \mathrm{~mL}$ of MPG twice daily is labor intensive. In the present study, MPG was delivered as a drench to have better control of the treatments, but it also can be mixed with concentrates. Monopropylene glycol also can be used as a tool to understand the interaction between nutrition and reproduction, and this may reveal new knowledge that makes it possible to use strategic supplementary feeding to improve the fertility of seasonal-breeding pasture-fed primiparous dairy cows.

\section{ACKNOWLEDGMENTS}

The authors acknowledge the contribution of the Dexcel Dairy Cattle Fertility Team, especially Viliami Taufa, who assisted with sample collection and trial management; technical assistance from Pat Laboyrie and the Dexcel No. 5 Dairy farm staff; and statistical analysis by Barbara Dow. The support of Agri-feeds also is acknowledged. This research was funded by the New Zealand Foundation for Research Science and Technology.

\section{REFERENCES}

Beam, S. W., and W. R. Butler. 1999. Effects of energy balance on follicular development and first ovulation in postpartum dairy cows. J. Reprod. Fertil. Suppl. 54:411-424.

Blache, D., L. M. Chagas, M. A. Blackberry, P. E. Vercoe, and G. B. Martin. 2000. Metabolic factors affecting the reproductive axis in male sheep. J. Reprod. Fertil. 140:1-11.

Breier, B. H., and P. D. Gluckman. 1991. The regulation of postnatal growth: Pathways and function of the somatotrophic axis. Livest. Prod. Sci. 27:77-94.

Burke, C. R., S. McDougall, and K. L. Macmillan. 1995. Effects of breed and calving live weight on postpartum ovarian activity in pasture-fed dairy heifers. Proc. N. Z. Soc. Anim. Prod. 55:76-78.

Butler, W. R., R. W. Everett, and C. E. Coppock. 1981. The relationships between energy balance, milk production and ovulation in postpartum Holstein cows. J. Anim. Sci. 53:742-748.

Butler, W. R., and R. D. Smith. 1989. Interrelationships between energy balance and postpartum reproductive function in dairy cows. J. Dairy Sci. 72:767-783.

Canfield, R. W., and W. R. Butler. 1990. Energy balance and pulsatile LH secretion in early postpartum dairy cattle. Domest. Anim. Endocrinol. 7:323-330.

Dieleman, S. J., and M. M. Bevers. 1987. Effects of monoclonal antibody against PMSG administered shortly after the preovulatory LH surge on time and number of ovulations in PMSG/PG-treated cows. J. Reprod. Fertil. 81:533-542.

Downing, J. A., J. Joss, P. Connel, and R. J. Scaramuzzi. 1995. Ovulation rate and the concentration of gonadotrophic and metabolic hormones in ewes fed lupin grain. J. Reprod. Fertil. 103:137-145.
Emery, R. S., N. Burg, and L. D. Brown. 1964. Detection, occurrence and prophylactic treatment of borderline ketosis with propylene glycol feeding. J. Dairy Sci. 47:1074-1079.

Flux, D. 1950. The effect of undernutrition before calving on the quantity and composition of milk produced by two-rear-old heifers. J. Agric. Sci. 40:177-184.

Formigoni, A., M. C. Cornil, A. Prandi, A. Mordenti, A. Rossi, D. Portetelle, and R. Renaville. 1996. Effect of propylene glycol supplementation around parturition on milk yield, reproduction performance and some hormonal and metabolic characteristics in dairy cows. J. Dairy Res. 63:11-24.

Gluckman, P. D., J. J. Johnson-Barrett, J. H. Butler, B. W. Edgar, and T. R. Gunn. 1983. Studies of insulin-like growth factor-I andII by specific radioligand assays in umbilical cord blood. Clin. Endocrinol. (Oxf.) 19:405-413.

Grainger, C., G. D. Wilhems, and A. A. McGowan. 1982. Effects of body condition at calving and the level of feeding in early lactation on milk production of dairy cows. Aust. J. Exp. Agric. Anim. Husb. 22:9-17.

Grummer, R. R., J. C. Winkler, S. J. Bertics, and V. A. Studer. 1994 Effect of propylene glycol dosage during feed restriction on metabolites in blood of prepartum Holstein heifers. J. Dairy Sci. 77:3618-3623.

Hales, C. N., and P. J. Randle. 1963. Immunoassay of insulin with insulin-antibody precipitate. Biochem. J. 88:137-146.

McDougall, S. 1994. Postpartum anoestrum in the pasture grazed New Zealand dairy cow. PhD Diss. Massey University, Palmerston North, New Zealand.

Miyoshi, S., J. L. Pate, and D. L. Palmquist. 2001. Effects of propylene glycol drenching on energy balance, plasma glucose, plasma insulin, ovarian function and conception in dairy cows. Anim. Reprod. Sci. 68:29-43.

Nett, T. M. 1987. Function of the hypothalamic-hypophysial axis during the post-partum period in ewes and cows. J. Reprod. Fertil. Suppl. 34:201-213.

Roche, J., P. Dillon, S. Crosse, and M. Rath. 1996. The effect of closing date of pasture in autumn and turnout date in spring on sward characteristics, dry matter yield, and milk production of springcalving dairy cows. Ir. J. Agric. Food Res. 35:127-140.

Roche, J. F., B. Mackey, and M. D. Diskin. 2000. Reproductive management of postpartum cows. Anim. Reprod. Sci. 60-61:703-712.

Schillo, K. K. 1992. Effects of dietary energy on control of luteinizing hormone secretion in cattle and sheep. J. Anim. Sci. 70:12711282.

Studer, V. A., R. R. Grummer, S. J. Bertics, and C. K. Reynolds. 1993. Effect of prepartum propylene glycol administration on periparturient fatty liver in dairy cows. J. Dairy Sci. 76:29312939

Thom, E. R., G. W. Sheath, A. M. Bryant, and N. R. Cox. 1986. Renovation of pastures containing paspalum 1. Persistence of overdrilled ryegrass and prairie grass and effect on seasonal pasture production. N. Z. J. Agric. Res. 29:575-585.

Wettemann, R. P. 1994. Management of nutritional factors affecting the prepartum and postpartum cow. Pages 155-165 in Factors Affecting Calf Crop. M. J. Fields and R. S. Sand, ed. CRC Press, Boca Raton, FL.

Zurek, E., G. R. Foxcroft, and J. J. Kennelly. 1995. Metabolic status and interval to first ovulation in postpartum dairy cows. J. Dairy Sci. 78:1909-1920. 